\title{
VALUE ATTITUDE TO HEALTH AS THE BASIS OF AN ACTIVE LIFE POSITION OF AN INDIVIDUAL
}

DOI: 10.36740/WLek202103223

\author{
Larysa V. Harashchenko, Svitlana G. Kondratiuk, Svitlana P. Palamar, Halyna 0. Vaskivska, Liudmyla L. Nezhyva \\ PEDAGOGICAL INSTITUTE BORYS GRINCHENKO KYIV UNIVERSITY, KYIV, UKRAINE
}

\begin{abstract}
The aim: Studying of the aspects that influence the formation of future teachers' values to health as the basis of an active life position of an individual. Materials and methods: To update the didactic aspects of the problem, we used the methods of analysis of normative and scientific sources, system analysis and generalizations, the results of our own empirical studies, materials of the questionnaire, active modeling of students' health value formation.

Results: The formation of a value attitude to the problem of health in future teachers is carried out under the following conditions: awareness of the importance of the value of health; changing the attitude of the individual to his/her own health and the health of others; knowledge of the factors influencing health, a conscious desire to lead a healthy lifestyle and make efforts to care for health, the use in the educational process of the operational model of forming students' value attitude to health by mastering the content of the course "Health-saving technologies in education" in order to form the ability of a systematic understanding of health-saving activities.

Conclusions: The formation of the value attitude of teachers to the problem of health involves taking into account all components of health and is possible provided within the condition of continuity of educational impact on the individual.
\end{abstract}

KEY WORDS: health attitude, physical education, motivation, mental health

Wiad Lek. 2021;74(3 p.II):690-696

\section{INTRODUCTION}

It is an indisputable fact that health is the basis and necessary condition of human life. Health is the most important value for a person. And just as indisputable is the maxim about the importance of forming a valued attitude to health. The interest in health is due to the tendency to deteriorate in today's complex socio-economic and environmental conditions [1]. Health is one of the most important indicators of the quality of education. The need of society to train preschool teachers who are able to implement the health paradigm in their own professional activities, implies the need to form in students a valued attitude to health. The concept of «values of health» includes the following positions [2,3]: mastering the content of this concept, understanding it as an important characteristic of socio-economic and cultural development of society, as well as the values of human existence; mastering the means and methods of preserving, shaping and strengthening their own health and the health of children;

active dissemination of the idea of health care among children, parents, teaching staff; improvement of knowledge, skills and abilities in the field of physical education and rehabilitation.

We are convinced that the formation of a valued attitude to health, as well as responsibility for individual health is a medical and pedagogical problem $[4,5]$. After all, in sight of modern research in the field of philosophy, medicine, psychology, pedagogy is a person whose foundation of life is health $[5,6,7]$.

\section{THE AIM}

The aim of the work was to study the aspects that affect the formation of future teachers' value attitude to health as the basis of an active life position. The hypothesis of the study is that an active life position of an individual can be formed by means of values to health, as the main component of human existence. Therefore, we need to determine the conditions for the formation of values of teachers to the problem of health. These include exploring the importance of health value to future educators; a change in an individual's attitude to his own health and the health of others as a result of mastering the knowledge of the factors that affect him, to explore the issues of motivation and conscious desire to lead a healthy lifestyle.

\section{MATERIALS AND METHODS}

To update the didactic aspects of the problem, we used the methods of analysis of normative and scientific sources, system analysis and generalizations, the results of our own empirical studies, materials of the questionnaire, active modeling of students' health value formation.

To achieve the aim of the research, we have conducted experimental task, during complying which we considered a belief that students' acknowledged and value relation to health depends on several factors.

The study was carried out in compliance with the main provisions of the ICH GCP and the Declaration of the 


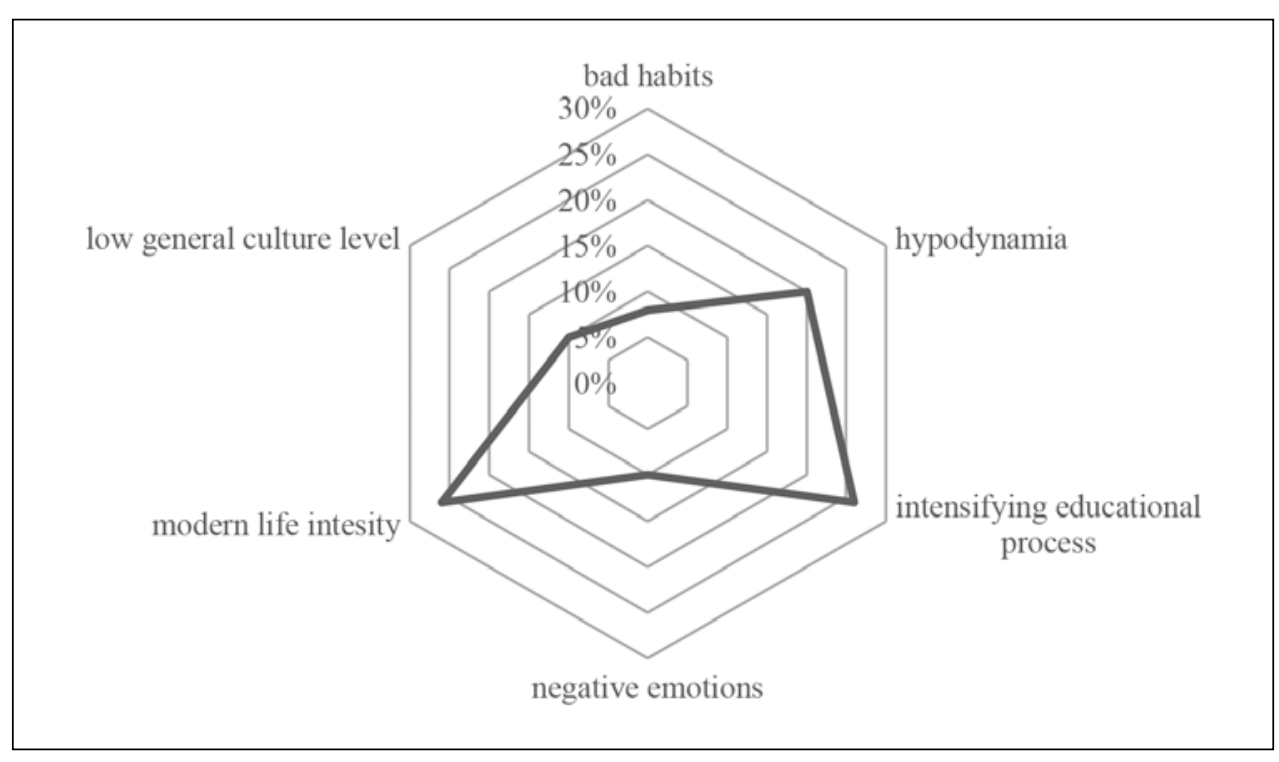

Fig. 1. Social factors which affect health (according to students' survey results)
World Medical Association "Ethical Principles for Medical Research with Human Involvement as an Object of Study" (Seoul, 2008), Council of Europe Convention for the Protection of Human Rights and Dignity of the Human Being with regard to the Application of Biology and Medicine, UN Convention on the Rights of the Child, the current regulations and laws of Ukraine, "Ethical principles of research among children and adolescents", approved by the Sociological Association of Ukraine, the main provisions of the International project «Health Behaviour in Schoolaged Children» (HBSC).

An essential component of compliance with the requirements of the survey technology was the preservation of anonymity and confidentiality of student responses. School leaders have been warned that confidentiality will be maintained for each school.

We conducted experiments using empirical method of conducting scientific pedagogical researches, that is, survey method. We chose half-open type survey (except for choosing an answer, the respondents could also express their own point of view).

To process results we used mathematic registration method, which allowed revealing certain qualities in the analyzed phenomena. Statistical assessment methods were used, namely the Mann-Whitney U-test rank criterion for comparing students' attitudes to health at different times intervals. To improve clarity and convenience of further findings analysis we used graphical method of representing experimental data. We also used methods of hypothesis, systemic analysis and generalizing, which allowed drawing conclusions in our research.

\section{RESULTS}

Let's consider results of the first stage. To define conscious and value attitude in students to their own health and children health, and also their readiness to imply physical and wellness activity in future, we conducted an experimental research in form of survey, including 357 students from different regions of Ukraine, who chose profession of preschool education. All the respondents (100\%) consider up-to-date issues of health value as a basic being value and necessity to form and maintain it since early age. Unfortunately, not all the students are aware that implementing health preserving activity mostly depends on pedagogue's professional competence.

As for social factors, $10 \%$ of respondents named as one of the reasons low level of general educational culture. $26 \%$ respondents defined as a reason for negative health state impact intensity of modern life. In their answers, $20 \%$ respondents talked about hypodynamia as a negative factor. $8 \%$ respondents mentioned their bad habits (smoking) that affect health. $10 \%$ respondents pointed out as one of the important negative factors negative emotions (irritability, hatred, aggressiveness). $26 \%$ respondents believe that their health is affected by intensifying educational process (a lot of tasks which have to be done with the computer etc.).

Answers to the second survey part on the first stage shaped out issues of powerful means to maintain and enforce physical health. Most of the students consider such means to be physical exercises, good nutrition, sticking to daily timetable. Most students defined their health as satisfactory (93\%), but morning exercises systematically do only $14 \%$.

Main reasons which hinder systematical physical trainings are considered by students to be: learning load, work and learn, absence of facilities to do physical trainings, inability for rational timing, absence of motivation (Fig.2).

Survey results enabled to find out that students do not pay enough attention to search and analysis of information on means of forming and maintaining their own physical and mental health, which, in turn, is a ground for further proficiency. Meanwhile, we state that future pedagogues lack skills of critical analysis for related information and enriching with it their life and professional experience. Also, they lack a specific need for looking for such information, which is shown by lack of sufficient motivation level for some $17 \%$. Survey findings analysis singles out 

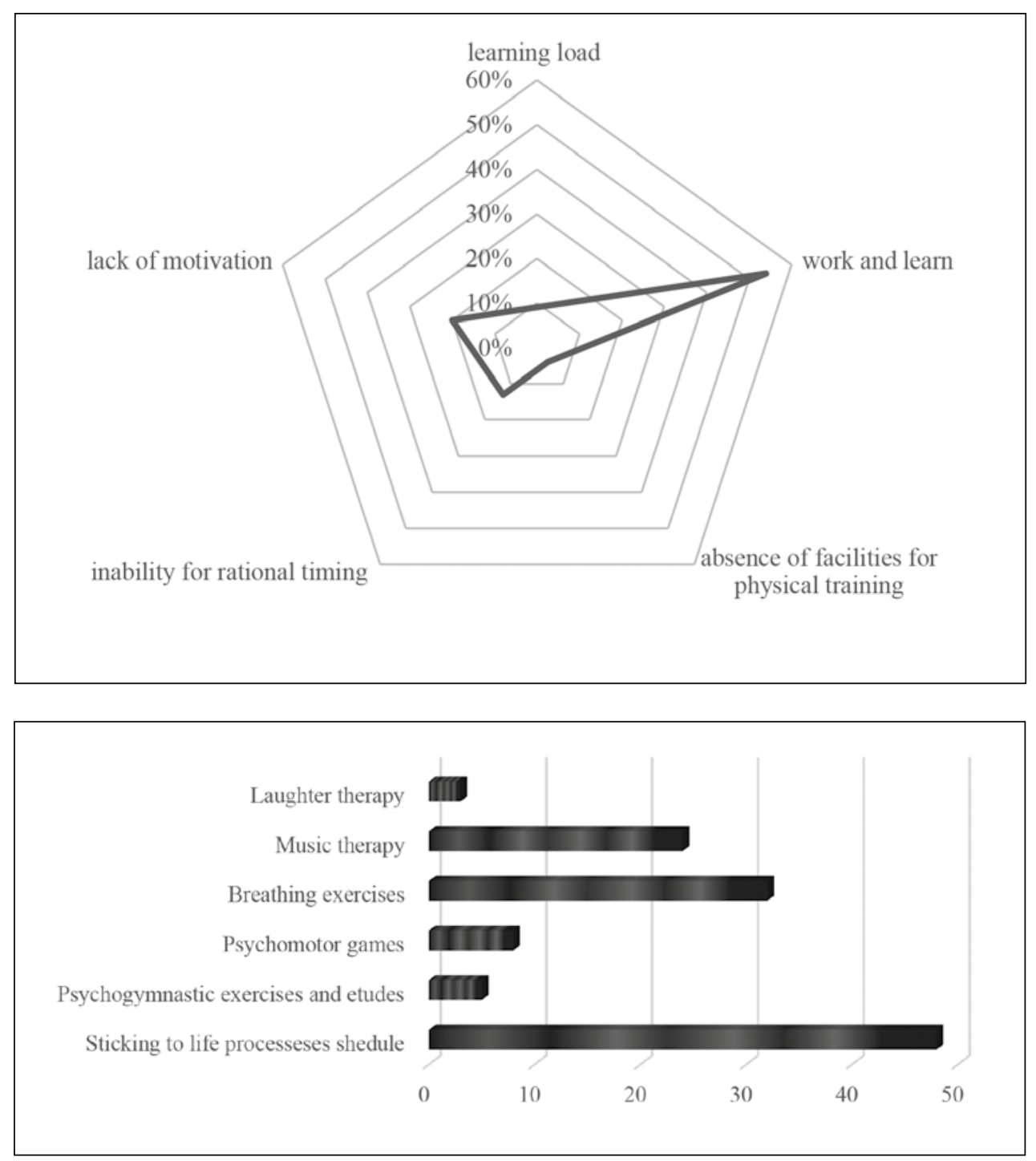

Fig. 2. Main reasons which hinder systematical physical trainings (according to students' survey)

Fig. 3. Means and methods of preserving and forming mental (intellectual and emotional) children's health in preschool education institutions an issue of consideration conditions and pedagogical instruments in future pedagogues value relation to health forming process, on the example of educational subjects teaching, in particular, methods of physical education for preschool children.

When we found out level of student's knowledge on means and methods of forming and preserving mental (intellectual and emotional) children's health in preschool education institutions on the first stage, the results were low (Fig.3).

Such methods as psych gymnastic exercises and etudes, psychomotor games and laughter therapy appeared [8] to be little-known among the students. Among the most wellknown were sticking to life processes schedule, breathing exercises and music therapy, but the general knowledge indicator among the students was very low.

Second stage results. After students learned course Methods of physical education of preschool children, all the respondents answered to first survey block, that one of the human and community well-being factors is health as an integrative human being quality. In particular, received indicators allow us to make a conclusion about views change on key factors which affect health. After studying the course, students defined as more important factors: hypodynamia and low general culture level. General increase by these factors was $11 \%$ and $9 \%$ respectively. This result proves unquestionable educational impact onto forming views and relations, because educational contents and direction of the course focused not only on forming professional competence, but also on worldview rethinking of health preserving issue.

Another factor to pay attention to is negative emotions [9]. Factor increase level is 6\%, which proves insufficient students' recognizing the importance of emotional health forming, which is reflected in emotional reactions and adequate behavior. Thus, we can draw a conclusion, that students do not fully recognize, that to realize wellness life position it is important to exclude from own behavior self-destroying habits and negative thinking.

An interesting factor to our consideration is decrease in level of parameters: modern life intensity and educational process intensifying [10]. These changes prove positive impact in forming professional competence in future pedagogues during studying the course Methods of physical 

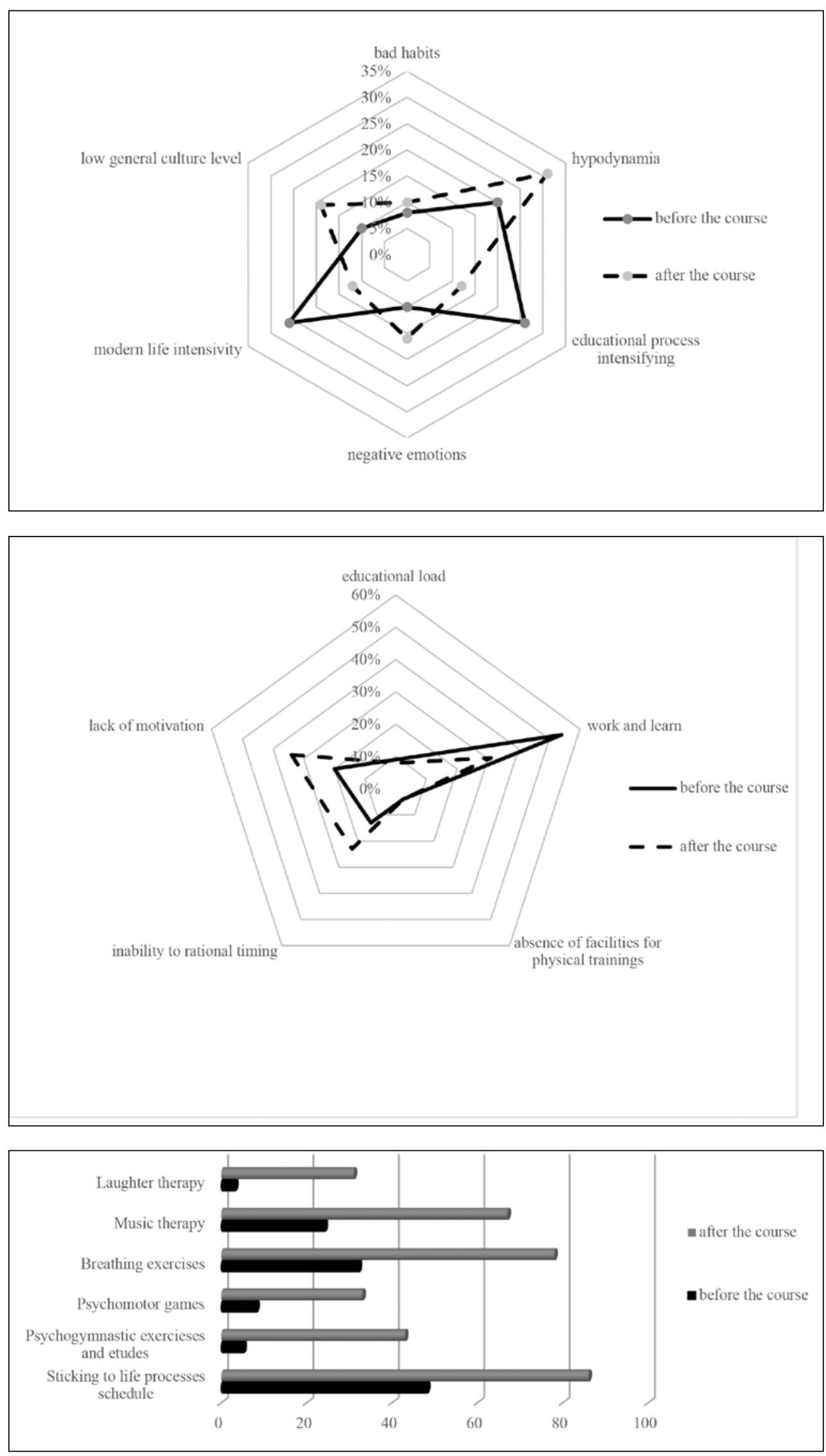

Fig. 4. Social factors that affect health level (according students' survey before and after the course)

Fig. 5. Main reasons which interfere systematic physical trainings (according to students' survey results before and after the course).

Fig. 6. Means and methods of preserving and forming mental (intellectual and emotional) children's health in preschool education institutions education of preschool children [11]. Most of the students note, that modern life pace and educational process intensifying are not key factors which affect health level. Graphical manifestation of relation change about influence of social factors onto health level is given below (Fig. 4). 


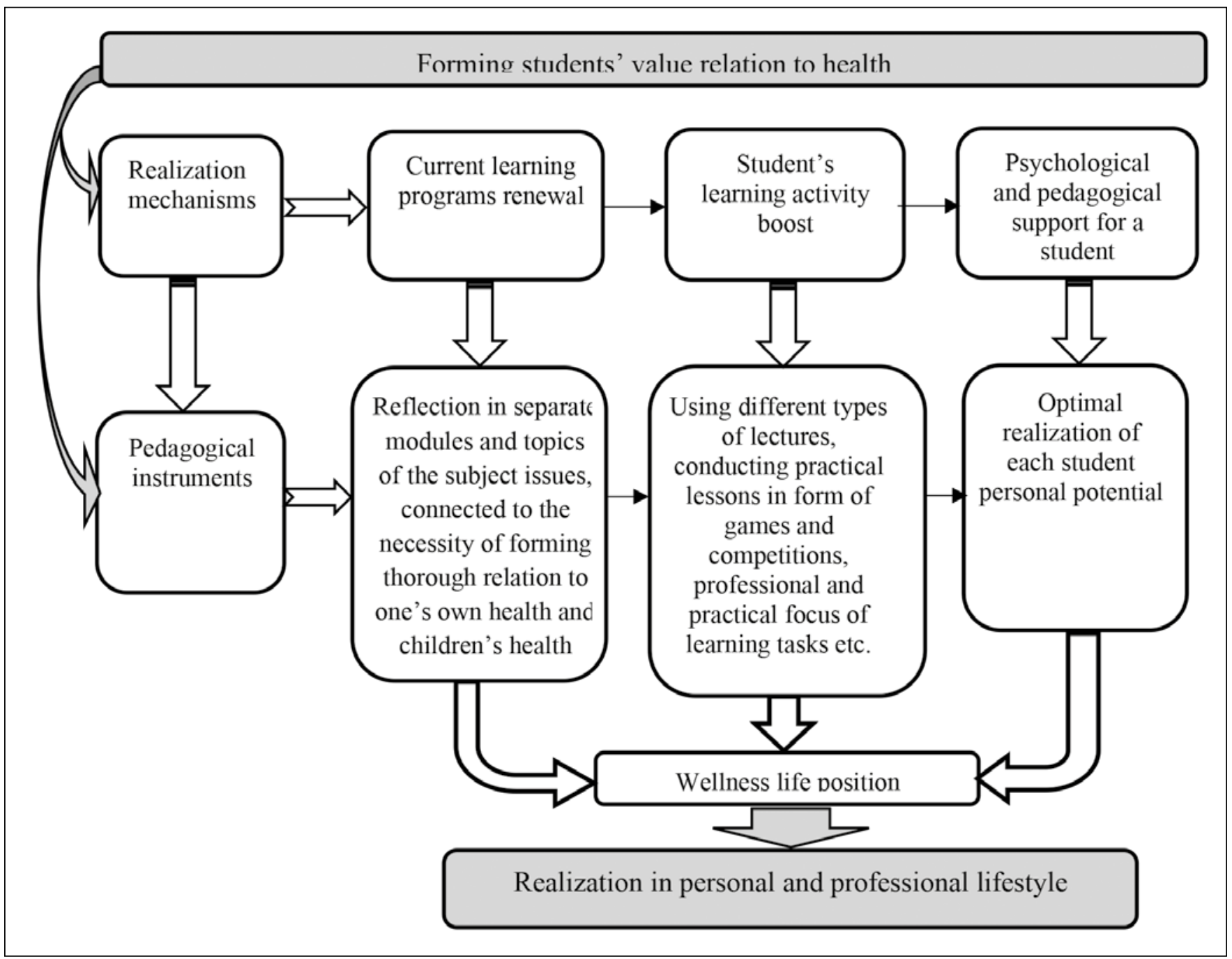

Fig. 7. Model of forming students' value relation to health..

The number of respondents, who know about ways of gathering information on health preserving and forming and physical development, is $39 \%$. However, this index shows that students do not pay enough attention to studying the results of modern researchers' works and preschool education institutions pedagogues on health preserving.

Comparative analysis of responds to survey second part questions showed that most of the students believe physical culture to be an influential mean to form and enforce health, full physical development, increasing organism workability. On the other hand, take systematical physical exercises began only $24 \%$ respondents, which is $6 \%$ more than at the start of the experiment. Main drawbacks to systematic physical trainings majority considers work and learn and lack of motivation, although the tendency on these parameters is drastically opposite. The increase in these parameters was $14 \%$ and $10 \%$ respectively. In turn, such result can be explained by gaining professional knowledge in the branch of physical culture lessons organizing process. Indicators of relations shift in this issue are presented below (Fig. 5).

It is interesting to know that $85 \%$ respondents consider physical culture and wellness work with children in pre- school education institution surroundings to be a priority direction, as health and full physical development are the basis to child's development as a personality.

In response to the third survey part $32 \%$ respondents mentioned that they cannot in full prepare effective means of impact on children's physical development and provide adequate psychological and pedagogical follow-up for different physical education work form. This index proves insufficient level of students' knowledge in professional activity bases in the branch of children's physical education and wellness, mastering the system of skills in preschool children physical education methods.

The issue of forming mental health in preschool children by means of health preserving technologies is processed only by $56 \%$ of students, although all the respondents understand the importance of providing psychological comfort. The results of students' knowledge in fields of breathing exercises, music therapy, psychomotor games, psychogymnastic etudes etc. rose, but none of the indexes reached $100 \%$, which proves relative negligence in students' relation to this issue (Fig. 6).

Comparative analysis of responds results to the third part questions of the first and second surveys showed the fol- 
lowing results: most of the students understand importance and necessity to provide psychological comfort for their own health and children's health. However, average number of respondents having some knowledge about mental health forming increased only to $36 \%$ comparing to $20 \%$.

A significant part of respondents $(65 \%)$ do not think about the importance of complex usage of children physical education means and appropriate connection of health preserving technologies in order to provide complex impact onto a child. Because of lack of professional and life experience students cannot acknowledge the fact that the more varied physical education and wellness means are used in preschool education, the more dynamic and effective will the process of optimal health forming and providing full personal development of the child be.

In terms of our research we should note that students changed their opinion on the importance of having information on means of preserving and forming own physical and mental health and children's health. They note a certain need in search for such information to enrich educational experience. Although, we have to say, that the students are not really motivated to search the information on health preserving in modern scientific sources and preschool education practice analysis [12].

It is positive that most of the students realize prioritizing physical culture and wellness work with children in preschool education institution surroundings. It is connected to processing contents component of the subject Methods of physical education of preschool children, carrying out practical lessons in a preschool education institution, and passing pedagogical practice $[13,14]$.

We found out that a significant part of respondents do not respect complex usage of children's wellness means and cannot properly estimate facilities to perform physical education and wellness of the children. It is related to the fact that the students have only a limited teaching experience and lack professional experience in preschool education institution surroundings.

According to the results, not all the students realize that performing health preserving activities mostly depends on pedagogue's professional competence.

It explains the fact that it is necessary to increase education quality, enforce professional and practical aspect of students' training, provide facilities to transform theoretic knowledge into effective practical actions.

\section{DISCUSSION}

Research analysis points out the issue of necessity to develop forming mechanisms in students of acknowledged value relation to health forming issue [15].

Let's look at conditions and pedagogical tools of forming future pedagogues' value relation to health on the example of teaching the subject Methods of physical education of preschool children.

First, it is working learning programs contents renewal, including course methods of physical education for preschool children. This subject has to change modern preschool education relation to a child, which presupposes conditions for optimal active lifestyle with high health level. In process of teaching a subject it is important not only to provide facilities to form skills of performing different activities form in children's physical education and wellness. To realize this task effectively it is crucial to form in future pedagogues the responsible relation to their health and children's health.

Motivation of forming students' health issue value relation is psychological and pedagogical support in process of self-development and self-establishment. That is why it is expedient to solve such tasks comprehensively taking into account the basic mechanisms of formation and development of the personality by means of the pedagogical tools used in educational process (Fig. 7).

Effectiveness of achieving future pedagogues' professional training tasks in the field of health preserving depends on educational process organization. Main contents of the course focuses on forming professional activity grounds, which is based on the interest to physical culture as an important wellness means, responsibility for health, processing adequate wellness skills and ability to provide a child with psychological and pedagogical support. It is logical, that acknowledging by future pedagogues' health value as a fundamental being value is a powerful means of gaining professional experience.

\section{CONCLUSIONS}

Students' professional experience processing in making an effective influence on health preserving and forming supposes effective organization of learning activities. Taking into account contents and educational direction of the subject, it is utterly important to form students' ability to consciously perceive material, critical thinking, and hypothesis making skill.

Using various practical tasks benefits to forming not only professional skills system, but also understanding and processing learning material, it's appropriate and effective usage in different professional situations.

It is critical for forming students' professional experience to form their skills to learn and analyze modern scientific researches results in the field of children's physical education and health, physical culture and wellness practice. We are convinced, that the ability to estimate psychological and pedagogical bases of children's physical education and wellness realization technology would benefit to processing and readiness to create optimal conditions to perform health preserving activity in preschool education institutions.

According to the research results we drew a general conclusion that the main factor of sticking to healthy lifestyle is defined by students as a desire to be healthy. The habit of taking care of own health should be formed since early years, so that health becomes one of the main needs throughout the whole life. Realization of proposed mechanisms and pedagogical tools of forming students value relation to health during the course benefits to improvement their mastering of the knowledge system in the 
field of theory and methods of children's physical education and wellness, as well as practical skills to organize and carry out physical culture and wellness events and providing psychological support in children's different activity types.

Future preschool education pedagogues' professional training system supposes their mastering of a skills system necessary to provide optimal conditions of preschool children education and development. Besides, another task of this training is forming future pedagogues' practical skills in organizing educational process, which is grounded on an important rule - interconnection and interrelation between children's education, development and health.

\section{REFERENCES}

1. MäättäS., Lehto R., Nislin M. et al. Increased health and well-being in preschools (DAGIS): rationale and design for a randomized controlled trial. BMC Public Health. 2015;15:402.

2. Bohinich 0. Priorytety u sferi fizychnoho rozvytku dytyny doshkilnoho viku. Optymizatsiia fizychnoho rozvytku dytyny u vitchyznianii systemi osvity [Priorities in the field of physical development of a child of preschool age, Optimization of the child's physical development in the domestic education system]: a monograph. Zaporizhzhia: Zaporizhzhya Regional Institute of Postgraduate Teacher Education. 2010, p.124-148. (in Ukrainian).

3. Lisnevska N.V. Pedahohichni umovy stvorennia zdoroviazberihaiuchoho seredovyshcha v doshkilnomu navchalnomu zakladi [Pedagogical conditions for creating a healthy environment in a preschool institution]. Institute of Education ProblemsThe National Academy of Educational Sciences of Ukraine. Kyiv. 2016. (in Ukrainian).

4. Gruzieva T. S., Galiienko L.I., Pelo I. M. et al. Health and lifestyle of students' youth: status, problems and ways of solution. Wiadomości Lekarskie. 2018;71(9): 1753-1758.

5. Palamar B. I., Vaskivska H. O., Palamar S. P. Didacticaspects of cognition of human as a bio-psycho-socio-cultural personality. Wiadomości Lekarskie. 2017; 70(5): 959-963.

6. Harashchenko L. Shliakhy vdoskonalennia fakhovoi pidhotovky maibutnikh vykhovateliv do zdoroviazberezhuvalnoi diialnosti [Ways to Improve the Training of Future Educators to Health-Saving Activities]. Bulletin of Luhansk Taras Shevchenko National University. Pedagogical Sciences 2020;7 (338): 195 - 201. doi: 10.12958/2227-2844-20191(324)-2-195-201. (in Ukrainian).

7. Vaskivska H. 0., Palamar S.P., Kondratiuk S.G. et al. Psychodidactic determinants of the development of children of preschool age. Wiadomości Lekarskie. 2018;71(6): 1207-1215.

8. Kondratiuk S., Kushnir I. Teoretychni osnovy vykorystannia ihor psykholohichnoho spriamuvannia v roboti z ditmy doshkilnoho viku [Application of psychologically aimed games in preschool education institution, theoretical basis]. Educological discourse. 2020; 3: 92-106. doi: 10.28925/2312-5829.2020.3.7. (in Ukrainian).

9. Vaskivska H.O., Palamar S.P., Vlasenko 0.M. Health in the civic students' value system: empirical analysis. Wiadomości Lekarskie. 2019;72(10): 1947-1952.

10. Harashchenko L. Rozvytok idei zdoroviazberezhennia u fizychnomu vykhovanni ditei v doshkilnykh zakladakh Ukrainy (druha polovyna XX - pochatok XXI stolittia) [The development of the healthcare idea in physical education of children in preschools in Ukraine (the second half of XX - the beginning of the XXI century)]. Borys Grinchenko Kyiv University. Kyiv. 2014. (in Ukrainian).
11. Palamar S., Nezhyva L., Vaskivska H.et al. Health-Saving Competence of Future Primary School Teachers: Indicators of Development III International Scientific Congress Society of Ambient Intelligence. 2020;129: 307-315.

12. Andriushchenko T.K. Teoretyko-metodychni zasady formuvannia zdoroviazberezhuvalnoi kompetentnosti v ditei doshkilnoho viku [Theoretical and methodological principles of formation of health competence in preschool children]. South Ukrainian National Pedagogical University named after K. D. Ushynsky, 2015. (in Ukrainian).

13. Bielenka H., Bohinich O., Mashovets M. Zdorovia dytyny - vid rodyny [Child's health - from the family]. Kyiv: SPD Bohdanova A. 2006. (in Ukrainian).

14. Harashchenko L.,Polovina 0. Eco-education of children of pre-school age: health-security approach. Volume 3. Sciemcee Publishing. London. 2019: 281: 93-105.

15. Bobrytska V. I. Theoretical and methodological bases of formation of healthy way of life for future teachers in the process of science study. Institute of Pedagogy and Psychology of Vocational Education Academy of Educational Sciences of Ukraine. Kyiv. 2006. (in Ukrainian).

The studies were carried out as part of the planned research work "New strategy for professional training of education specialist in terms of European integration", (2016-2021, state registration No. 0116U002963). The study has no external funding.

\section{ORCID and contributionship:}

Larysa V. Harashchenko: 0000-0001-5004-6136 ${ }^{A, B, D}$

Svitlana G. Kondratiuk: 0000-0003-4037-6291 A, B,D

Svitlana P. Palamar: 0000-0001-6123-241X ${ }^{A, B, D}$

Halyna O. Vaskivska: 0000-0002-8714-8512 A,E,F

Liudmyla L. Nezhyva: 0000-0001-9520-0694 A,E,F

\section{Conflict of interest:}

The Authors declare no conflict of interest.

\section{CORRESPONDING AUTHOR}

Svitlana P. Palamar

Pedagogical Institute of Boris Grinchenko University

18/2 I.Shamo Blvd, 01601 Kyiv, Ukraine

tel: +380507444635

e-mail: svetlana_03@ukr.net

Received: 25.11 .2020

Accepted: 10.03 .2021

A - Work concept and design, B - Data collection and analysis, C - Responsibility for statistical analysis,

$\mathbf{D}$-Writing the article, $\mathbf{E}-$ Critical review, $\mathbf{F}-$ Final approval of the article 